Article

\title{
Pre-Columbian Earthworks in Coastal Amazonia
}

\section{Stéphen Rostain}

UMR 8096 “Archéologie des Amériques” CNRS, Panthéon-Sorbonne University, Maison René Ginouvès, 21 allée de 1'Université, Nanterre 92023, France; E-Mail: stephen.rostain@mae.uparis10.fr; Tel.: +33-1-46-69-25-02; Fax: +33-1-46-69-25-08

Received: 4 December 2009 / Accepted: 28 January 2010 / Published: 2 March 2010

\begin{abstract}
As in other parts of Amazonia, pre-Columbian Indians have profoundly modified the coast of the Guianas. Between 650 and 1650 AD, Arauquinoid people occupied a territory that was approximately $600 \mathrm{~km}$ long and used the raised field technique intensively before the European conquest. They erected thousands of raised fields of various shapes, dug canals, ditches, and pathways, and built artificial mounds to establish their villages. All these earthworks changed forever the face of the coastal flooded savannas and their ecology. Such labor was probably organized under the leadership of a central authority: it seems that Arauquinoid societies were organized in a chiefdom system. Statistical calculations, based on the known surface area of raised fields and on their estimated productivity, suggest a population density of 50 to 100 inhabitants per $\mathrm{km}^{2}$. Pre-Columbian inhabitants of the Guianas coast carefully organized, managed and "anthropisized" their territory following a specific pattern.
\end{abstract}

Keywords: Guianas; coast; savanna; agriculture; raised field; Arauquinoid; pre-Columbian

Without mentioning the flooded Savannas that do not seem suitable for cultivation ([1], p. 51; author's translation). 


\section{Introduction}

Until recently, it was inferred that slash-and-burn agriculture was predominant in Amazonia during pre-Columbian times. Today, some archaeologists hypothesize that the first agricultural inhabitants of the rainforest most likely employed more complex techniques [2], which left important and long-lasting modifications in the landscape [3]. Classical techniques were generally used to cultivate most of the forested part of Amazonia. On the other hand, Indians had to develop specific agricultural techniques for flooded areas like the várzea, flooded savannas or swamps. One of them was to build raised fields associated with drainage canals in flooding lowlands. Such earthworks profoundly changed and affected the landscape, to the extent that the legacy of this pre-Columbian land use remains visible today [4].

In the Guianas, raised fields were found in Suriname in 1956 by the engineer H. Dost, who described them [5,6]. In 1988, looking for similar structures in French Guiana, I found thousands of raised fields and canals west of Cayenne Island [4]. Between 1988 and 1991, I have managed a scientific project on these earthworks that includes archaeologists, anthropologists, historians, botanists, geomorphologists, pedologists, hydrologists and specialists of aerial imagery. Between 2003 and 2006, a new project focused on the western coast of French Guiana and coastal Suriname. This article summarizes the main observations and interpretations resulting from that research, addressing the origins of landscape diversity in the region.

\section{The Coastal Amazonia and Its Agricultural Potential}

The Guianas have a geographical and cultural uniformity that is distinct within Greater Amazonia. They cover some 1.8 million square kilometers $(\mathrm{km})$ and include parts of five countries: Venezuela, Guyana, Suriname, French Guiana and Brazil (Figure 1). The Guianas are delimited by the Orinoco River on the north, by the Atlantic Ocean to the east, by the Amazon River to the south, and by the Rio Negro and the Casiquiare channel to the west. The Casiquiare is a geographical anomaly that connects two different basins: the Upper Negro (itself in the watershed of the Amazon) and the Upper Orinoco. Since the Guianas are bordered by water from rivers or the ocean, they form a vast continental island inside Amazonia [7]. The coastal Guianas include the Amaruco delta (the right side of Orinoco) in Venezuela and the littoral of Guyana, Suriname, French Guiana and of the state of Amapá in Brazil.

The hinterland tropical forest covers $90 \%$ of coastal Guianas. Seen from the sky, it has the appearance of broccoli. The inland is composed of thousands of juxtaposed small hills, which form a "half orange" relief. The forest is one of the most variegated vegetation formations in the world, containing more than 5,200 known vascular plants. There are, on average, between 100 and 200 tree species per hectare and 1,300 tree species are actually known in French Guiana [8]. Extended savannas cover the southern borders of Guyana and Suriname. 
Figure 1. Map of the Guianas.

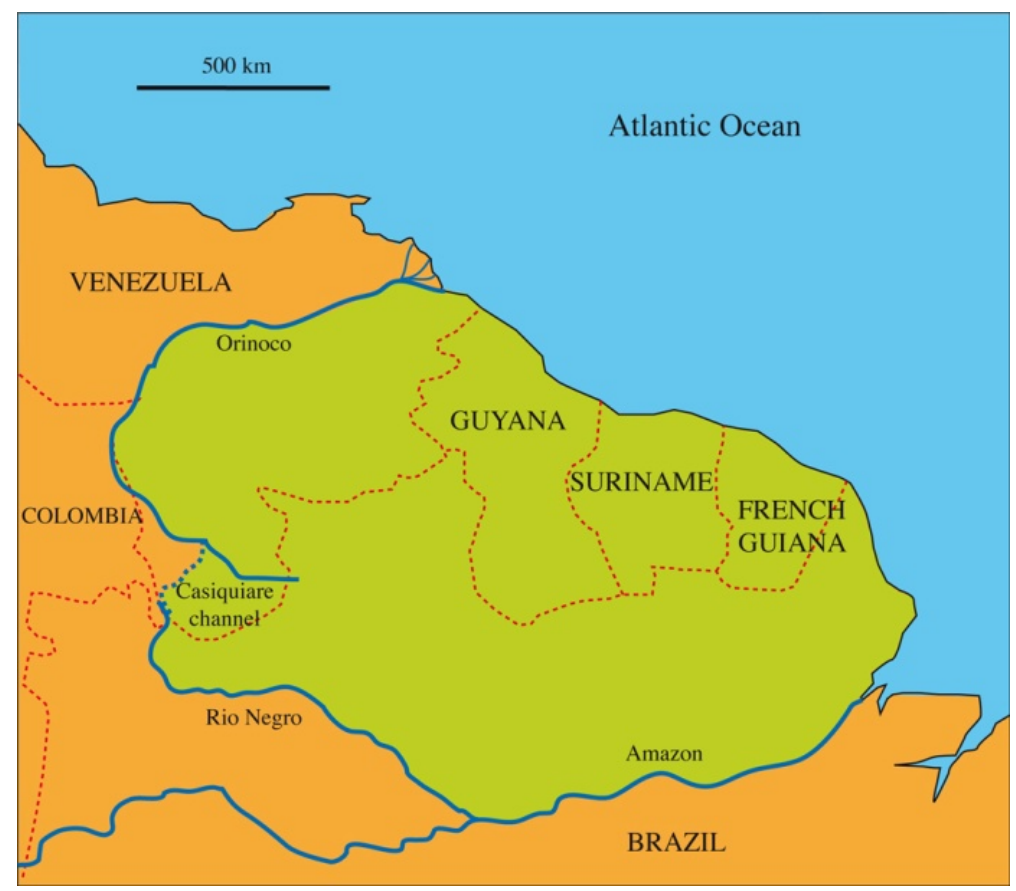

The Guianas coastal zone is a large Quaternary sedimentary plain stretching some 1,600 km between the mouth of the Amazon and the Orinoco Delta. It is relatively narrow in French Guiana, where it is between 5 and $40 \mathrm{~km}$ wide; it reaches a maximum width of $180 \mathrm{~km}$ in western Suriname and eastern Guyana. Outcrops of the rocky shelf only emerge on the French Guiana coast in the shape of small hills in Oyapock Bay, Cayenne Island and the lower Kourou. The coastal plain of the Guianas is made up of two formations. The young coastal plain is a low swampy plain bordered by mangroves on the mud flats along the seashore. It is partially subjected to tidal shifts, with seawater sometimes flooding as much as $2 \mathrm{~km}$ into the mangroves. Flooded savannas and swamps, with isolated patches of forest, dominate the old coastal plain. The marshes are made of the Coswine clay formation, are covered by sandy bars and by narrow and elongated sandy ridges (cheniers) that run parallel to the seashore. Cheniers are thought to represent old beaches, measuring tens of meters wide and reaching sometimes more than $100 \mathrm{~km}$ in length (Figure 2). Although these dry sandy ridges were preferred locations by the pre-Columbian inhabitants for establishing their villages, Europeans during colonial times dismissed them as inadequate for settlement and agriculture, even arguing that their putatively noxious air could cause lethal fevers. Conversely, pre-Columbian Indians intensively occupied this environment and profoundly modified and even constructed its many landscapes. In other words, pre-Columbian inhabitants contributed considerably to the diversity of landscapes in the Guianas. 
Figure 2. Old coastal plain of French Guiana showing an elongated chenier between marshes.

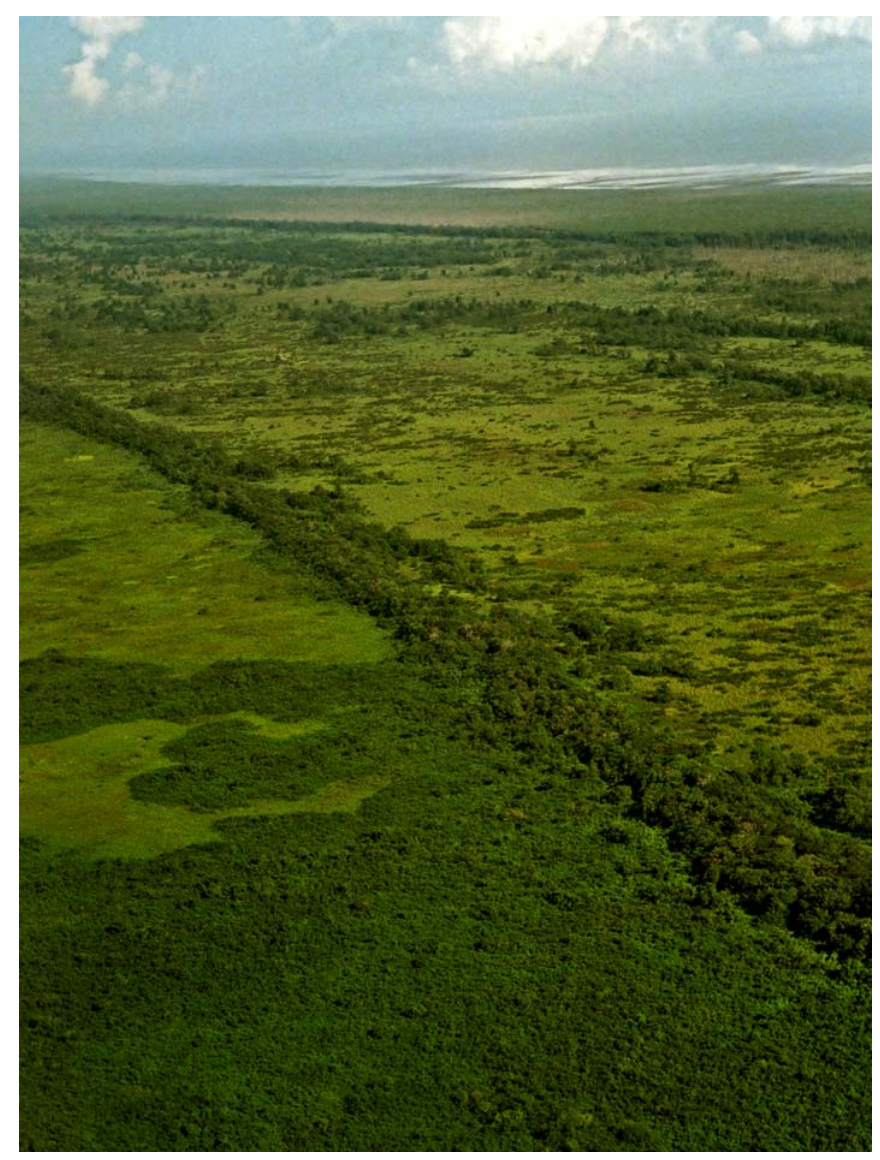

There are only two main techniques to cultivate flooded areas like swamps. Europeans used polders: they dug canals to drain water from large areas. Using slave labor, Dutchmen built hundreds of hectares of polders along the Cottica River, east of Paramaribo. In French Guiana, Europeans first cultivated highlands by the slash-and-burn technique because "its first settlers, frightened by the enormous abundance of rain and the conditions of the lowlands, always very moist and sometimes completely flooded, decided in favor of the hills or highlands, a shelter from this kind of recurrent deluge" ([1], pp. 53-54; author's translation). In 1769, under the influence of the civil engineer Samuel Guisan - who had witnessed the construction of polders in Suriname - slaves began building polders east of Cayenne Island. These polders are located between the Oyapock River and Cayenne Island: very few were made west of Cayenne. Today, only a few polders are still in use, for rice cultivation in the Nickerie district of western Suriname and at Mana, in the far west of French Guiana.

Pre-Columbian Indians in the Guianas employed a completely different technique to cultivate in the swamps: the raised-field technique. Basically it is the opposite of the polders technique, because instead of digging canals in order to dry a large area, it is based on building mounds above the water level. The goal is to concentrate fertile matter from the organic horizon level of the swamp. To raise the height was not always sufficient to protect cultivated plants from flooding, so canals and ditches were also dug for the purpose of controlling water level variations. Thus, like the polders, the pre-Columbian raised fields in the Guianas were also built as a way of managing excess water (Figure 3). 
Figure 3. The circled area indicates the remains of a raised field under modern polders near Mana, western French Guiana.

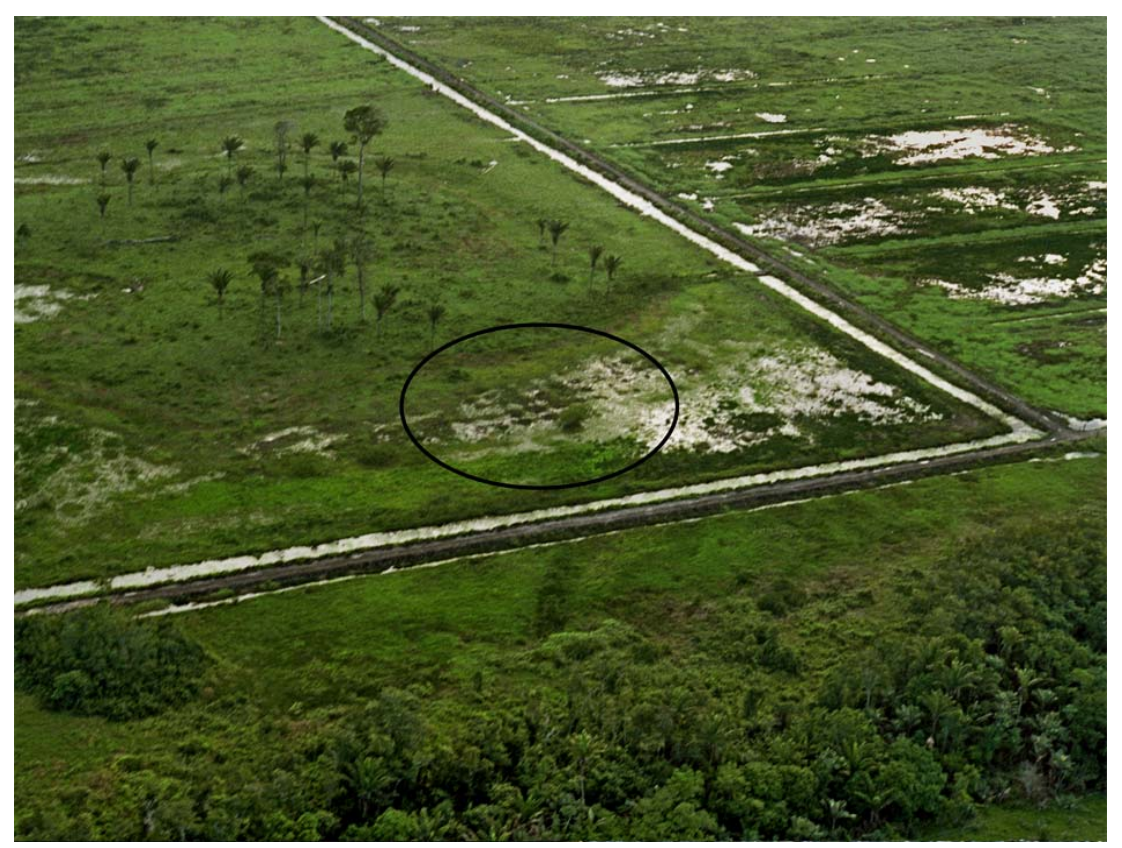

In 1988-1990, I studied and reported on numerous small earth mounds present in the seasonally flooded savannas [4). They share remarkable characteristics (Figure 4): they were always located in flooded or seasonally flooded areas; they were often distributed in parallel or perpendicular rows that follow a grid; they were organized groups of rounded or rectangular mounds often associated with nearby sandy ridges; the shape of the mounds (whether round, square, rectangular or elongated) seems to be related to the depth of the water; and artificial ditches frequently appeared associated with these mounds. It was difficult to avoid the conclusion that they were raised fields.

Figure 4. Raised-field complex of Piliwa near Awala, western French Guiana showing the mound distribution in a grid.

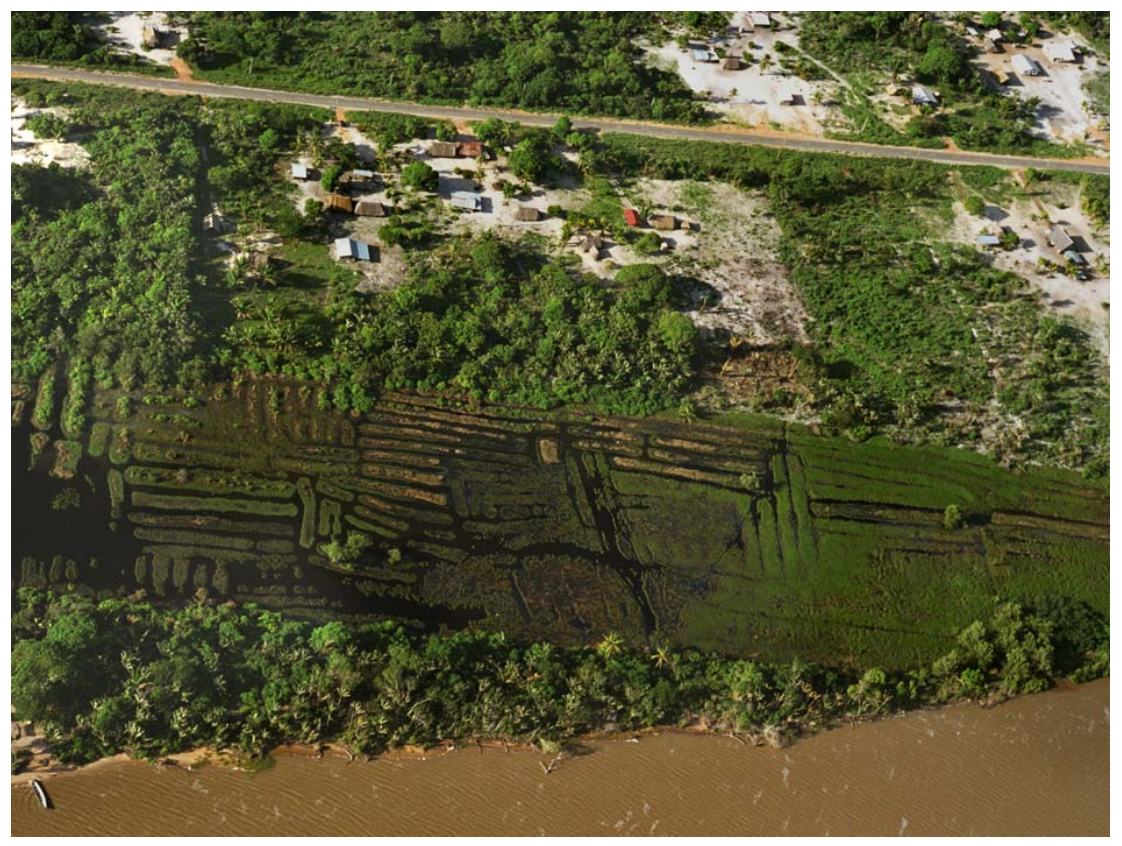


Ancient raised fields are known from various parts of South America, especially around the periphery of the Amazon rainforest. Most of these earthworks date back to the first millennium AD, but some were made as early as $1000 \mathrm{BC}$ and used up until European conquest and even beyond. They are located in savannas or Andean valleys, generally flooded areas. In fact, the main reason for building raised fields is to control excess water for agricultural purposes.

Numerous raised-field complexes are located in the flooded savannas of Amazonia, in Bolivia, Colombia, Venezuela and the Guianas. Others have been discovered along the Pacific coast of Colombia, Ecuador and Chile. Raised fields were first found and studied in South America during the 1960s [9]. In the Llanos de Mojos in Bolivia, raised fields occupy at least 6,000 hectares. In this area, there is a large diversity of pre-Columbian earthworks, like canals, ponds, fish weirs, causeways and pathways, and artificial earth mounds [10]. For instance, the Loma Salvatierra mound was occupied from 500 to $1400 \mathrm{AD}$ [11]. An embankment encloses an area of 20 hectares around an eight meter high mound. The residential area is separated from the cemetery. A network of canals, ditches, small mounds and pathways organizes the surroundings. In Colombia, hydraulic systems of the San Jorge cover a surface of 90,000 hectares [12]. There are successions of parallel canals distributed perpendicularly to rivers. Several artificial residential and funerary platforms were built near these raised fields. In Venezuela, in the Llanos de Apure, elongated raised fields are distributed perpendicular to a river [13]. In the La Tigra site, a network of canals drains 35 hectares of raised fields. The total length of these canals is $3.8 \mathrm{~km}$ [14]. On the Pacific coast, raised fields have been reported on the south-central coast of Chile [15]. Covering 50,000 hectares, the Guayas Basin complex around Guayaquil, in Ecuador, is the largest reported raised field site in the Pacific Coast [16].

Several raised-field complexes are also located in the high Andean valleys in Colombia, Ecuador and Peru. Here, besides the drainage function, a thermal objective is added because the warmer temperature in the mounds prevents the destruction of crops by frost. In the savanna of Bogotá, hundreds of elongated raised fields have been dated to $1100 \mathrm{AD}$, with maize and bean microfossils identified in them [17]. In the northern highland valleys of Ecuador, pre-Columbian chiefdoms built high ceremonial platforms and ridged fields a few centuries before the European conquest. In the Cayambe valley, some raised fields were buried under ash deposits after an eruption of the Quilotoa volcano dated to $1280 \mathrm{AD}$, which gives a terminus post-quem for the use of the fields [18]. Sixteenth to seventeenth centuries records also mention cultivation on raised fields (camellones) in this area. Near Lake Titicaca, in the Puna area of Peru and Bolivia (circa. 4,000 m above see level), there are 122,000 hectares covered by raised fields [19]. Their building began circa $1000 \mathrm{BC}$ and they were used continuously until 1450 AD.

Most of the Amazonian and Andean raised fields (camellones) are elongated and distributed in various ways. Raised fields of the Guianas, especially those from French Guiana, are unique because the majority are round. This makes them distinct from other examples recorded in South America. 


\section{Earthworks in Coastal Guianas}

\subsection{Raised Fields}

Raised fields had two main functions: to secure a dry location for cultivation and to concentrate fertile material. Thousands of pre-Columbian raised fields surrounded by ditches are located in the coastal zone of the Guianas (Figure 5). Raised fields are classified on the basis of their size, shape and topographical location [20). This last criterion is indicative of differences of adaptation to the hydrographical conditions and to the nature of the soil. Four types of raised field are distinguished:

Figure 5. Map of the raised-field complexes of the Guianas coast.

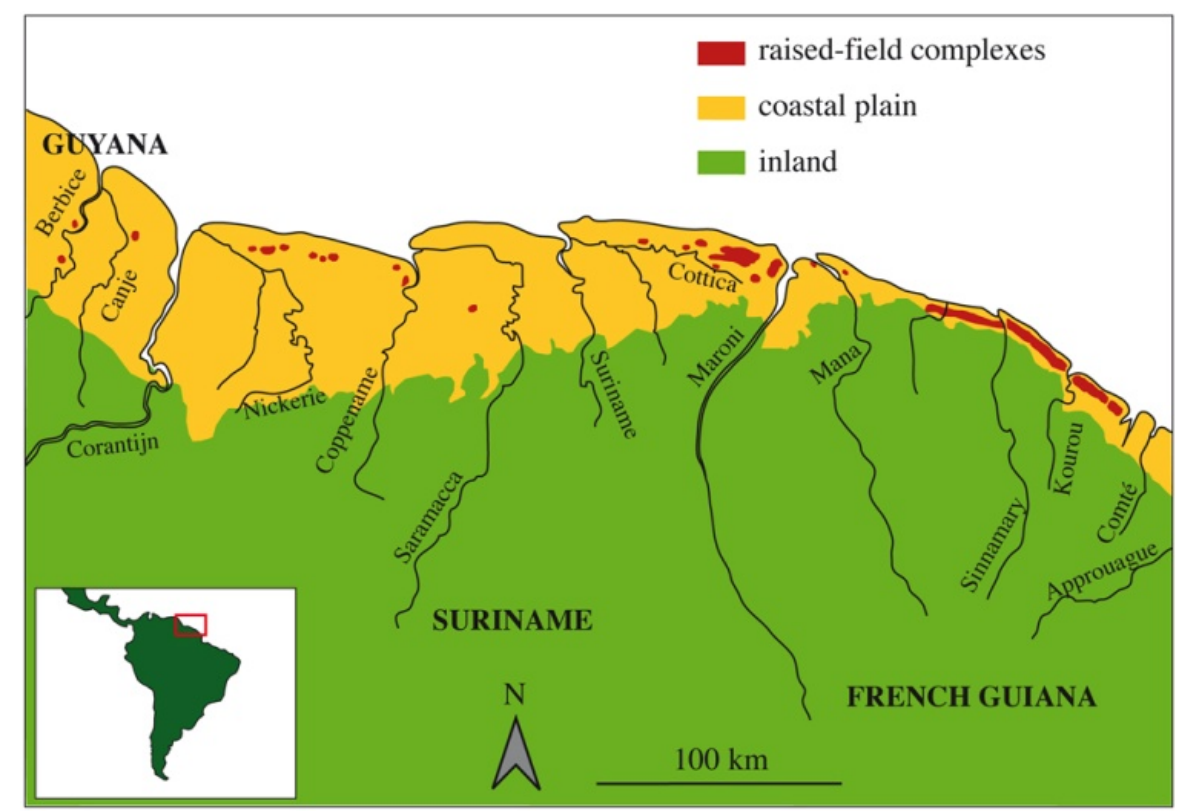

- (1) Ridged fields are found in the three Guianas. They are elongated and narrow, measuring between 1 and $3 \mathrm{~m}$ in width, 5 to $30 \mathrm{~m}$ in length and 30 to $80 \mathrm{~cm}$ in height (Figure 6). They take the shape of the slope between the sandy ridges and the swamp. Their distribution is related to the altitude and the water level. At the foot of the Quaternary sand ridges, elongated raised fields are positioned in the direction of the slope to allow for easy drainage. Near the top of the sand ridges, the ridged fields are arranged perpendicular to the slope for optimal water retention. In Suriname, two types of raised fields are distinguished: regular and irregular ones. On the western coast of Suriname, irregular raised fields are located near the residential mounds. They are distributed arbitrarily or arranged in groups of 2 to 10 or 15 . They are oval shaped, measuring between 3 and $6.5 \mathrm{~m}$ wide, 8 to $140 \mathrm{~m}$ long, with an average of 4-5 × 20-30 $\mathrm{m}$ [21]. In eastern Guyana, 787 rectangular raised fields are distributed in a linear configuration. Their size ranges from 1.7 to $6.9 \mathrm{~m}$ wide, 5 to $8.2 \mathrm{~m}$ long and 50 to $170 \mathrm{~cm}$ high. They are associated with a residential mound along the Canje and the Berbice rivers [22]. 
Figure 6. Elongated raised fields.

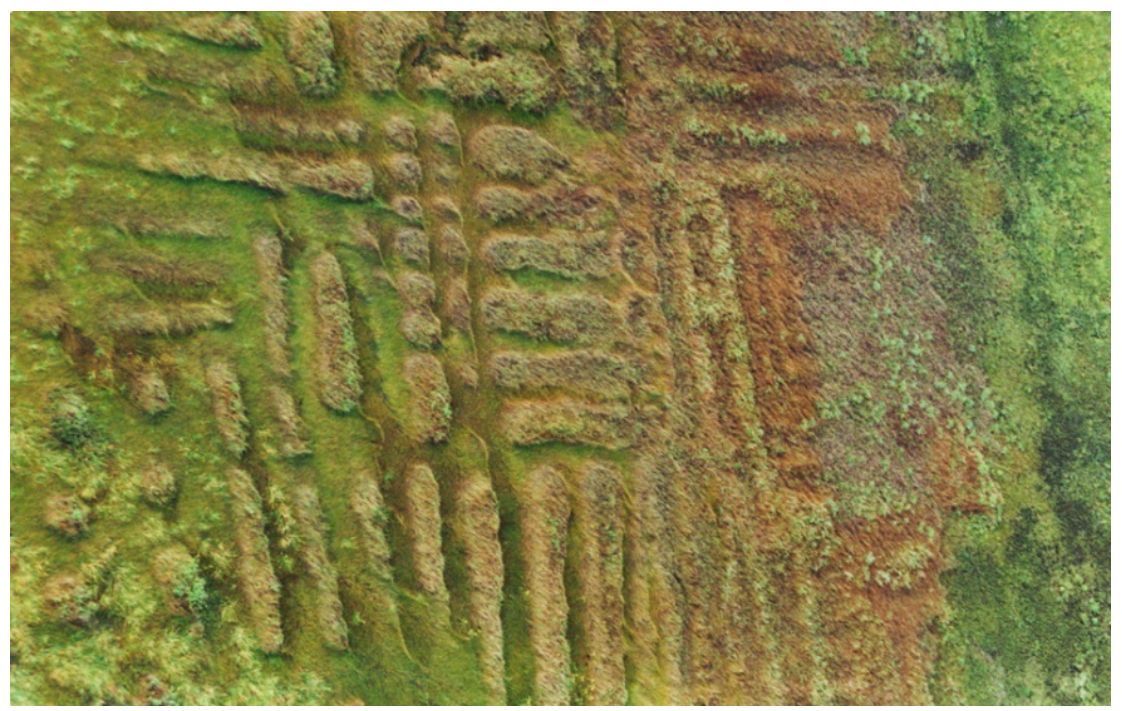

- (2) Large raised fields range in size from 2 to $5 \mathrm{~m}$ diameter and from 30 to $100 \mathrm{~cm}$ height (Figure 7). These raised fields, generally round in shape, are found in eastern Suriname and around Kourou and Sinnamary, but they are more square or rectangular near Cayenne Island. On the eastern coast and in some areas of the western coast of Suriname, the regular raised fields are rounded-off rectangular or square shapes [21]. Their size ranges from 3 to $4 \mathrm{~m}$ wide, 4 to $30 \mathrm{~m}$ long and 50 to 100 $\mathrm{cm}$ high. They are clearly visible on aerial photographs. These large raised fields are located in the most flooded areas and their sizes are smaller in the deepest swamps.

Figure 7. Large raised field.

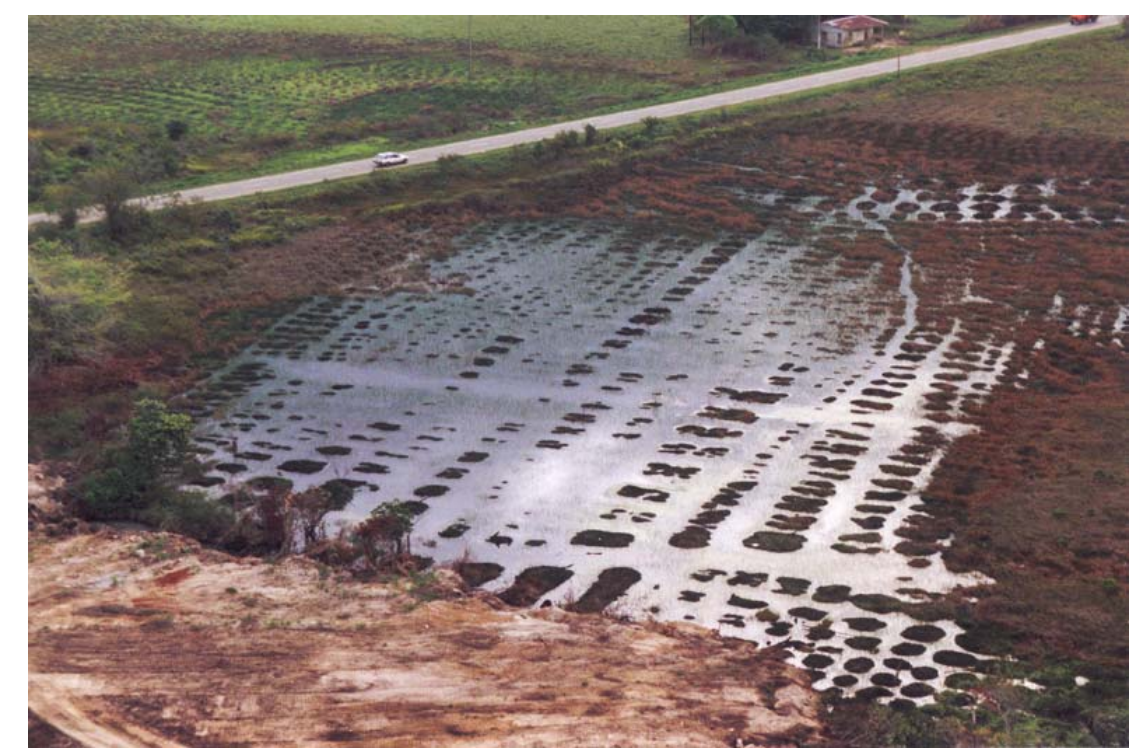

- (3) Medium-sized raised fields can be round, square or rectangular, and are only found in French Guiana (Figure 8). Their size ranges from 1.5 to $3 \mathrm{~m}$ diameter and 20 to $30 \mathrm{~cm}$ high. They occur in large clusters. They were in open areas, but vegetation has grown on these areas since the Indians left, and today, they are sometimes under forest cover so it is not possible to see them on aerial photographs. 
Figure 8. Medium raised fields.

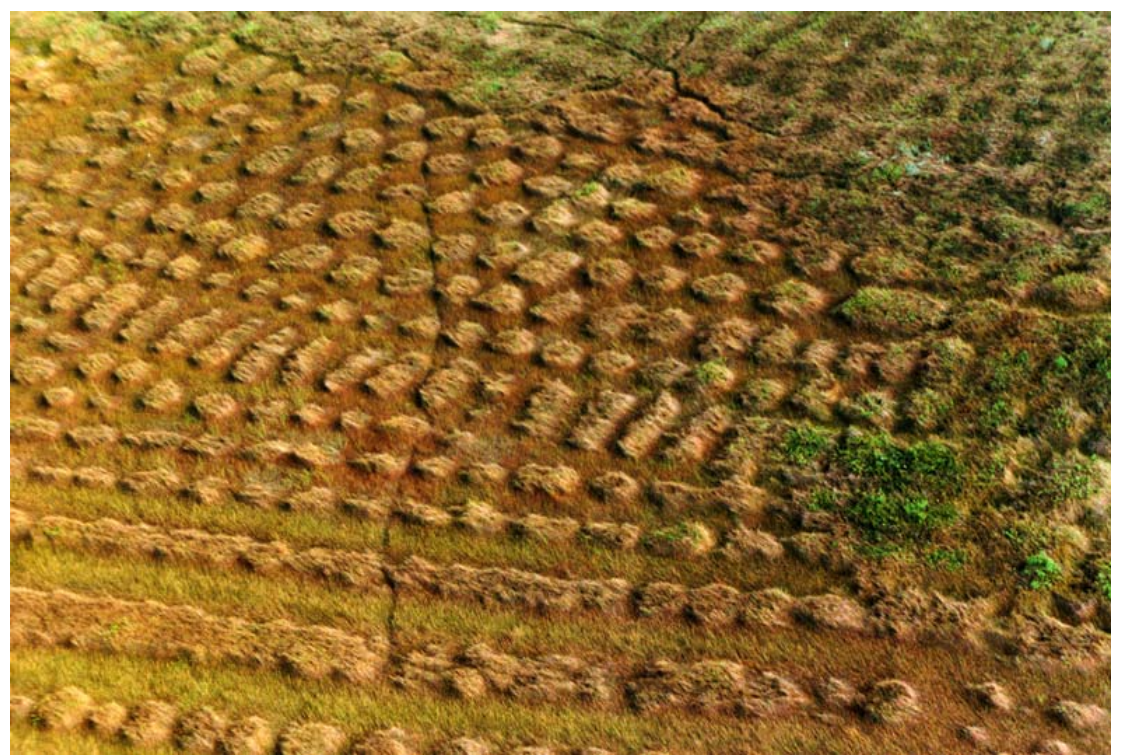

- (4) Small, rounded raised fields range in size from 50 to $100 \mathrm{~cm}$ in diameter and from 20 to $50 \mathrm{~cm}$ in height. They are only found in French Guiana and are almost invisible on aerial photographs at 1:10,000. Known cases were found during ground survey. They cover the entire surface of the seasonally flooded savannas, which become completely dry in August.

Figure 9. Small raised fields covering a savanna near Sinnamary.

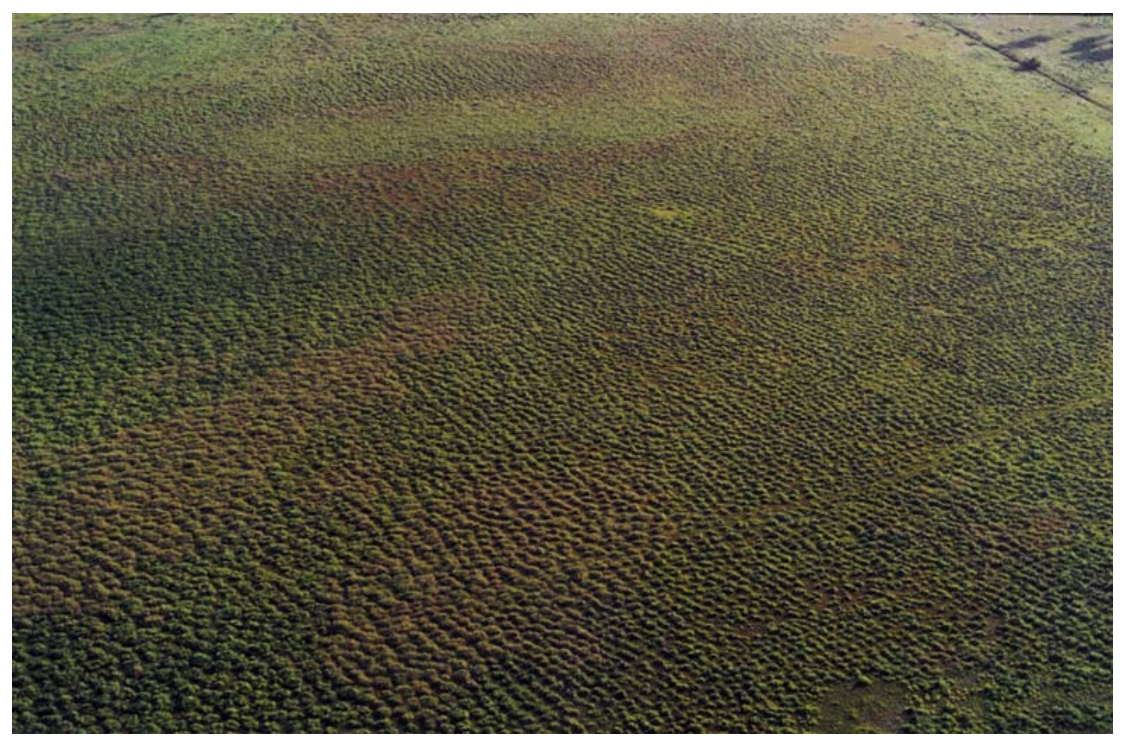

Along the French Guiana coast, raised fields are generally arranged roughly in squares, and often, the largest are located in the deepest and wettest areas. The raised fields seem to be organized by homogeneous areas, on average 0.5 hectares each, placed side-by-side. A precise stereoscopic analysis of aerial photographs compared with field data shows that the raised fields were made and disposed according to the differences of water level during the two annual seasons. In fact, water is the main physical constraint. The location of raised fields between the high and low areas in the landscape suggests a precise selection by the Indians. However, this was not always enough to prevent drowning 
of the raised fields. For that reason, it was necessary to surround some groups of raised fields by a belt ditch. In some cases, the checkerboard distribution of the ridged fields also reflects the need to control the water level. In some areas, the whole surface of the lower area is covered by raised fields, and in other areas, only the edge of the sandy ridges has raised fields [20].

A general study of the raised fields emphasizes local differences along the Guianas coast. Six main categories of organization and types of raised fields can be distinguished from west to east. In eastern Guyana, elongated raised fields are distributed perpendicularly to a river. In western Suriname, complexes are made of small groups of elongated raised fields. In eastern Suriname, up to the Mana River in French Guiana, parallel ridged fields are in flooded depressions. Between the Iracoubo and Sinnamary rivers, savannas are covered by a large number of rounded medium-sized raised fields. Between the Sinnamary and Kourou rivers, rounded or square raised fields associated with ridged fields are located in the savannas and along the edge of the sandy ridges. Between the Kourou River and Cayenne Island, rounded or square raised fields cover the savannas like the area between the Iracoubo and Sinnamary rivers. These variations can represent cultural, chronological or technical differences.

\subsection{Ditches and Canals}

Ditches made by pre-Columbians are difficult to recognize, because after several centuries, alluvium and vegetation tend to obliterate them. Moreover, Creole farmers had also made small canals during the twentieth century, which might be confused with the pre-Columbian ones. Stereoscopic interpretation of aerial photographs shows that there are numerous water lines that do not follow the natural flow, and must have been made by people.

Ditches were made to improve water control. Belt ditches are small and curved waterlines $1-2 \mathrm{~m}$ in width, perpendicular to the direction in which the water naturally flows. They enclose some groups of raised fields. They are relatively narrow at their extremities and generally form a pond at the center. These ditches functioned to prevent too much water near the raised fields during the rainy season. They also most likely served as water reserves during the dry season.

Canals are straight and regular ditches, larger than belt ditches, located near the raised fields. They measure about $2 \mathrm{~m}$ wide and they can have a length of $150 \mathrm{~m}$. They were used for the drainage of excessive water and, perhaps, as water tanks or fishponds. Some of them are exceptionally long and could serve for canoe travel. For example, there are two long canals near the Mana River [23]. One of them measures about $2 \mathrm{~km}$ long, $3 \mathrm{~m}$ deep, $4 \mathrm{~m}$ wide at the bottom and $21 \mathrm{~m}$ wide at the top. The modern Cariban-speaking Kali'na Indians of the Awala village mention that these canals served in the past to connect the settlements of the lower Mana. Similar very long canals are also found in Suriname, running perpendicularly from a sand ridge and often connected to a raised fields complex [24].

Ponds were sometimes dug near a sand ridge or in the middle of a swamp. They were generally rounded or irregular in shape, and their diameter did not exceed $10 \mathrm{~m}$. It is probable that they were used as water tanks and fishponds. 
Figure 10. Belt ditches measuring $90 \mathrm{~m}$ longcircling a raised-field complex near Kourou (photo IGN 1987).

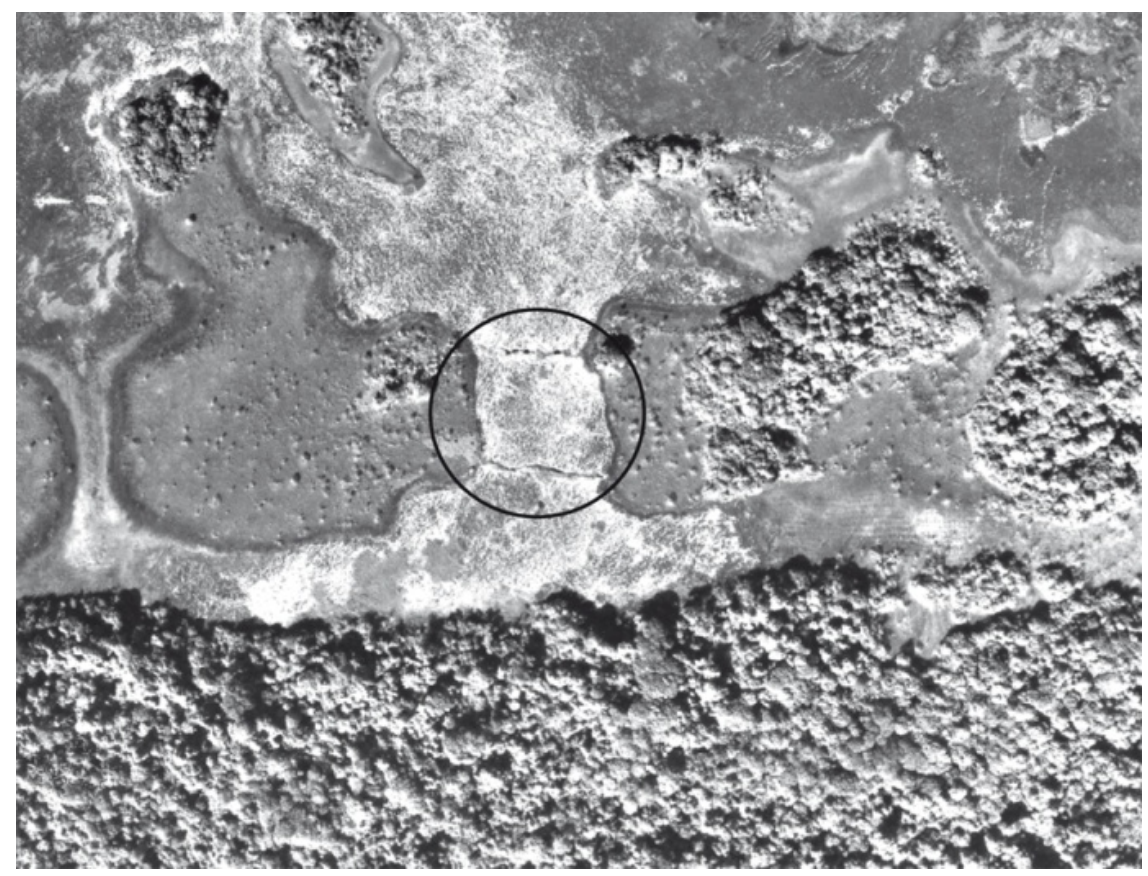

\subsection{Residential Mounds}

Artificial residential mounds are associated with raised-field complexes in various countries of South America. In the Llanos of Apure, in Venezuela, several Arauquinoid mounds and raised fields have been found. In western Suriname and eastern Guyana, between the Berbice and the Coppename rivers, sandy ridges are absent, so Hertenrits people had to build rounded clay mounds above the water level to erect their villages. At least eight mounds were erected on a landscape where fresh, brackish and salt waters met, but other possible artificial mounds have been reported in this area [25].

Figure 11. Hertenrits mound view from the raised fields, western Suriname coast (photo Geijskes, coll ${ }^{\circ}$ Stichting Surinaams Museum).

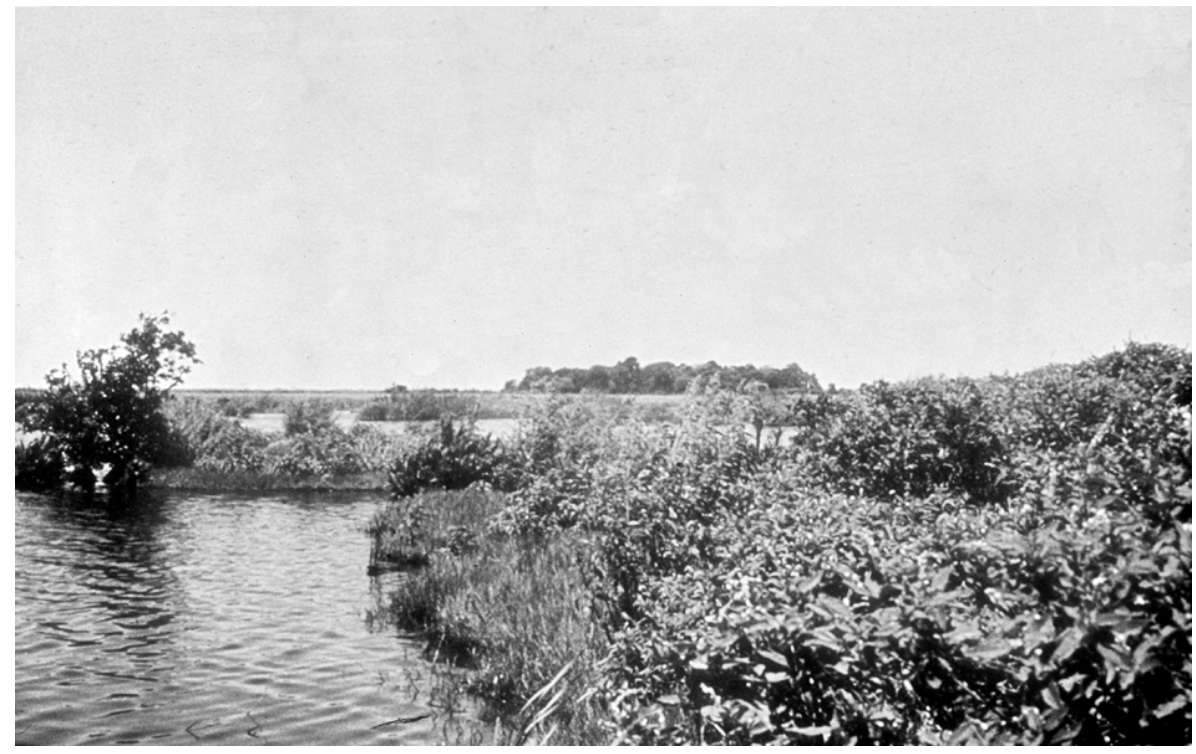


Circa 300 AD, a Barrancoid group raised two mounds. From 650 AD, Arauquinoid communities built new mounds. Their territory extended to cover a region some $210 \mathrm{~km}$ long and $25 \mathrm{~km}$ wide. At 200 to $320 \mathrm{~m}$ in diameter, $2.5 \mathrm{~m}$ high, and with a raised area estimated at 4 hectares, Hertenrits is the largest of the six Arauquinoid mounds (Figure 11). The total quantity of earth mobilized has been estimated as 14,000 truckloads [21]. The Hertenrits mound was occupied during a long period between 650 and $1250 \mathrm{AD}$ [25], being built progressively, layer by layer. The area around the mounds was inundated with fresh-water at the end of the wet season. Humans modified some water lines to connect them or to improve natural drainage. A ditch of $20-100 \mathrm{~m}$ wide surrounds the Hertenrits mound. Mounds were built up from circa 600 AD layer by layer from the clay immediately around the mound. Five wharves of $20 \mathrm{~m}$ long and at least $1 \mathrm{~m}$ deep are disposed on the periphery to receive canoes. Two smaller satellite mounds were built diametrically opposite, equidistant from Hertenrits: Wageningen-1 is $4 \mathrm{~km}$ to the east and Wageningen-3 is $3 \mathrm{~km}$ to the west. Raised fields were built between the mounds. They are rectangular or elongated, distributed in irregular and scattered groups of mainly 2 to 10-15 plots. Shallow seasonally inundated canals run radially, connecting the Hertenrits mound to raised fields and to the two other mounds. These canals were used as pathways during the dry season and as waterways during the rainy season, strongly suggesting that the three mounds were occupied at the same time. The inhabitants of Hertenrits organized and managed their territory in a precise and specific manner.

Figure 12. Human modifications in the Hertenrits surroundings with the three residential mounds (redrawn after Boomert 1980).

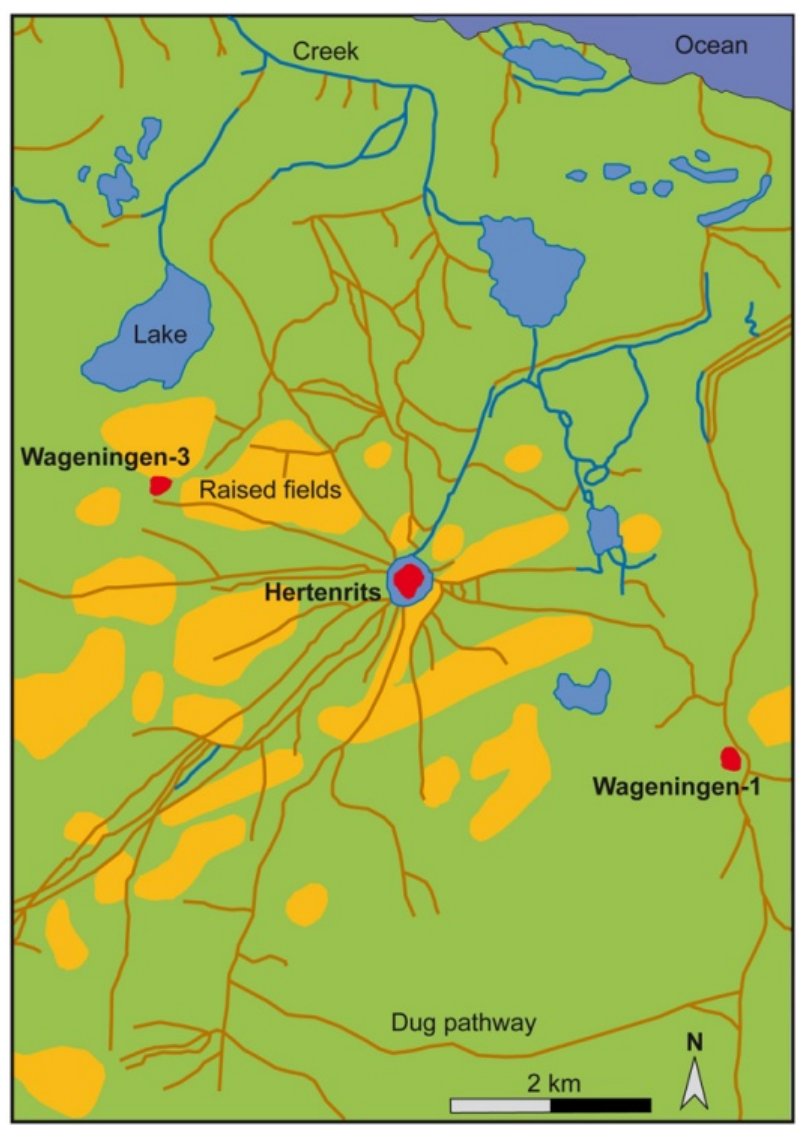

Note: Residential mound are red, canals are light brown and raised fields are orange. 
Suriname mounds are useful to estimate the ancient human impact on the vegetation. Almost 50\% of the plants and tree species currently growing on the mounds have practical uses for modern Indian groups living in the interior [26]. In contrast, only $15 \%$ of the species in the forest are "useful or usable" for Indians. Thus, the percentage on the mounds is about four-times higher than in the surrounding, suggesting that the first inhabitants facilitated the vegetational assemblage on mounds. These particular species survived after the site abandonment, in a manner similar to other archaeological sites in the forest, where it is common to find specific plants and trees like kapok cotton tree (Ceiba pentandra) or bamboo (Guadua spp.) (Bubberman, pers. com.; see also [27]).

\subsection{Causeways}

Causeways are frequent in Arauquinoid sites of the Llanos de Apure in Venezuela [28]. Four causeways have been found on the French Guiana coast, but it is still not clear whether they are pre-Columbian. They are oriented in a north-south direction and they generally cut through the swamps, connecting two west-east sand ridges or one sand ridge to the shore. West of the Kourou River, there are three causeways of 330 to $620 \mathrm{~m}$ in length and $5 \mathrm{~m}$ in maximum width (Figure 13). It is probable that these causeways were used to easily reach the shore from inland. In the Corossony North site, west of Sinnamary River, another raised pathway $400 \mathrm{~m}$ long and 5-8 $\mathrm{m}$ wide connects two sand ridges. Two canals, which form the banks of this pathway, were dug in order to rise above the water level.

Figure 13. Causeways ( see circled area) crossing a flooded area near Kourou (photo IGN 1987).

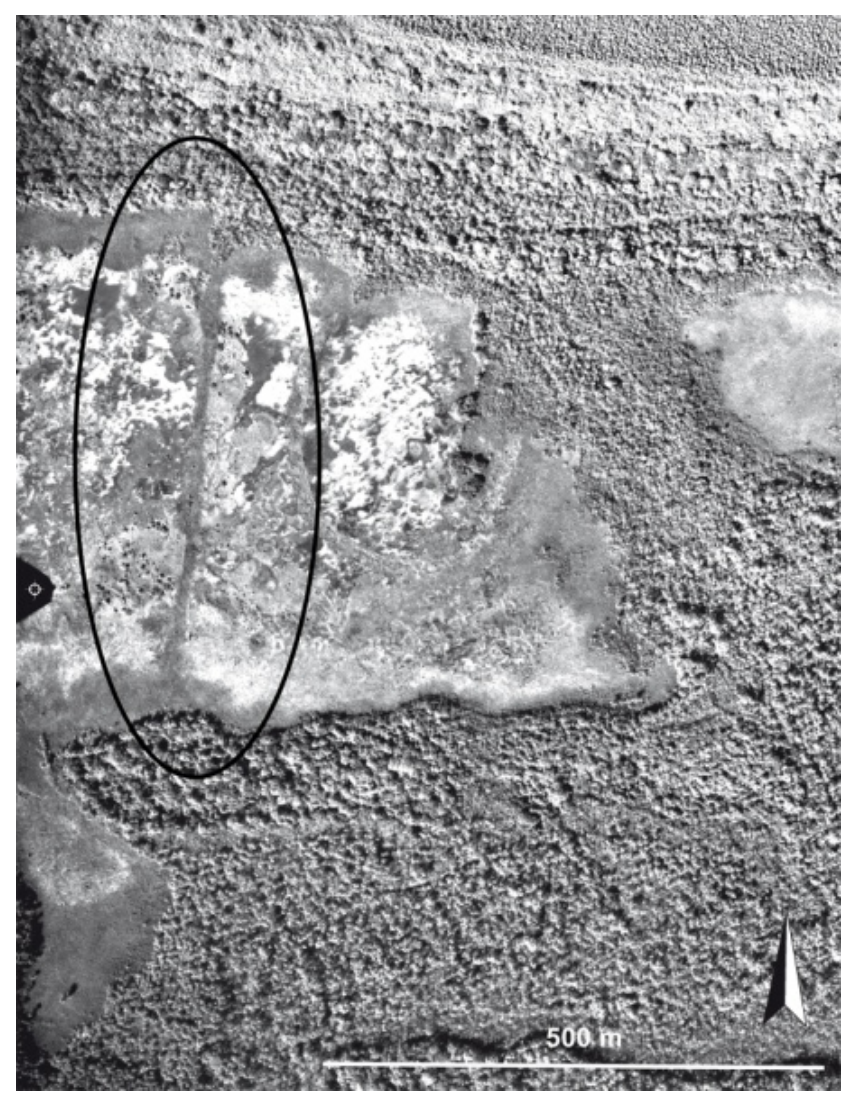




\subsection{Recent Earthworks}

Along the Guianas coast, extensive colonial earthworks were generally built to improve cultivating conditions. As was mentioned earlier, the most impressive constructions made by Europeans were the polders. Dutchmen drained thousands of hectares in Suriname. If there were only 23 sugar plantations in 1668 in Suriname, by 1800 there were 641 active plantations along the Para River and the lower courses of the Suriname and Commewijne rivers, and in the 1970s, 3,500 hectares of rice polders were irrigated in the Coronie District, on the western coast [29]. Polders were never so extensive in French Guiana, where most of them were built in the lower Approuague basin during the eighteenth century. Europeans dug long canals for circulation, like the Leroy canal near Kourou or Torcy canal in the lower Approuague in French Guiana.

Although recent farmers have also modified the landscape, they have done so on a reduced scale when compared to pre-Columbian inhabitants. They are considerably less responsible for the substantive landscape diversity we now observe than were the prehistoric people. The Saramaka, a group of escaped slaves who are now living along the Maroni River, sometimes build small and elongated raised fields [30]. The Creoles, black people living in French Guiana, make agricultural boards that are large, rectangular and low flat mounds on dry sandy formations. These raised areas are virtually never found in flooded savannas and they are smaller than pre-Columbian ones. In the dry areas, Creoles also dig square ditches to protect their houses from flooding and their cattle [4]. In the recent past, Haitian immigrants have made small, elongated and round, raised fields around Kourou (Figure 14). These are built in sandy and dry areas and never reach the size of pre-Columbian raised fields. It would appear that the agricultural technique these immigrants have employed originated in Africa. More recently, Europeans made ditches and causeways with machines in various places.

Figure 14. Modern small raised fields made on dry area by Haitians near Kourou.

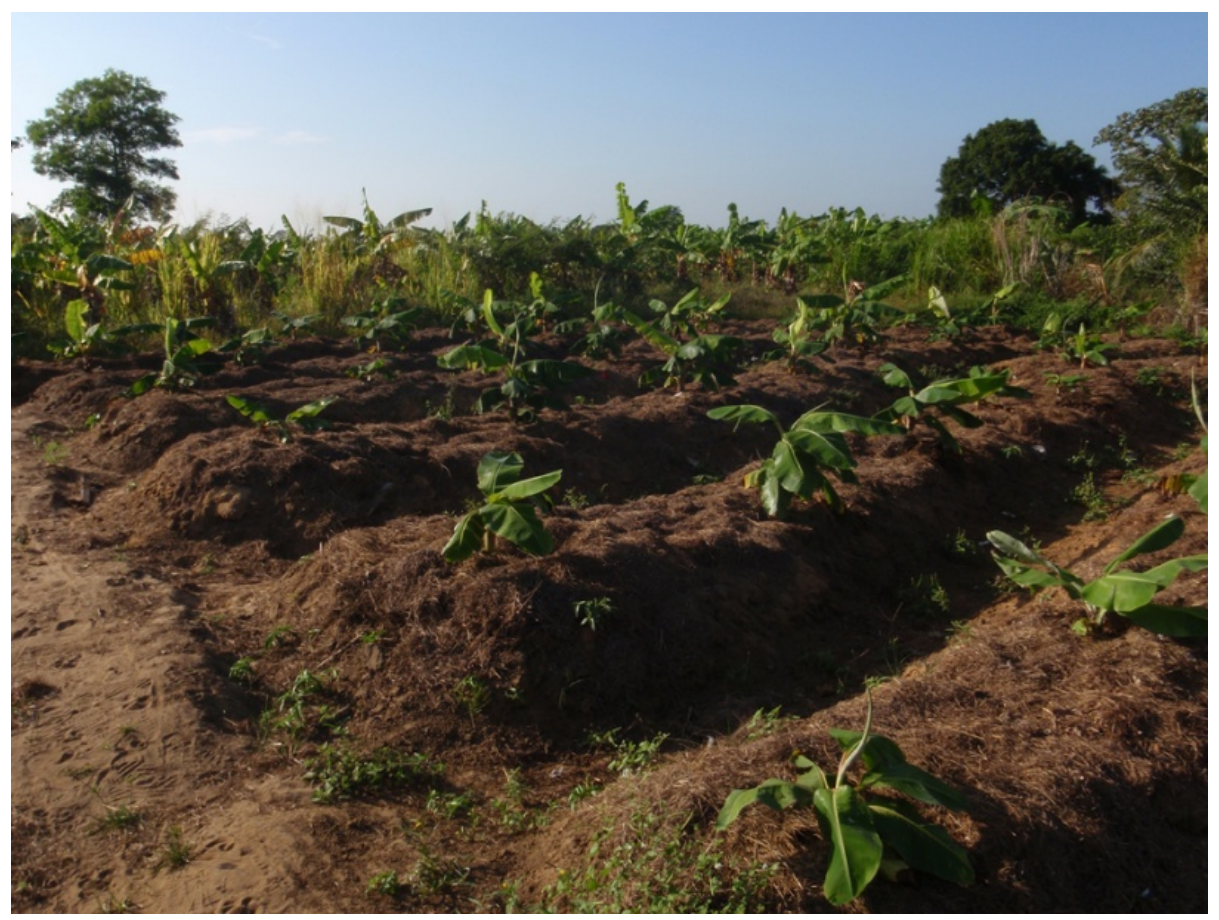




\section{Cultivated Plants}

The raised field technique is well adapted to the cultivation of roots crops [31), but a wide variety of crops can be planted. In Amazonia, bitter manioc (Manihot sp.), maize (Zea mays), yam (Dioscorea sp.) and sweet potato (Ipomoea batatas) probably were the main cultivated plants on raised fields. When they reach maturity, manioc tubers are found at depths of $25-30 \mathrm{~cm}$. They never dip below the water table, where they could rot, and that is why raised fields are always higher than $30 \mathrm{~cm}$. However, their roots still can reach the water table, even during the dry season.

Most of the available archaeological data suggests that maize and bitter manioc were the predominant cultigens on the raised fields in South America [32,33]. On the middle Orinoco, it seems that manioc was originally the main crop on raised fields, but from circa $800 \mathrm{AD}$, population growth corresponds to the introduction of maize [34]. In the eighteenth century, Juan Gumilla [35] describes a predominance of bitter manioc and maize, but also several other plants. Indeed, ethnography shows that Amazonian Indians generally cultivate several species in their gardens, not all of which are for food.

During the 2003-2006 project, earth samples were collected in various raised-field complexes of French Guiana. Magali Chacornac has conducted phytolith and pollen determination. Few phytoliths have been found, but significant amounts of pollen have been recognized [36]. The main plants were manioc, maize, and sweet potato. However, because pollen can fly long distances, these assemblages also include some contamination with allochthonous plants imported during colonial period. More data are given by artifacts found on the archaeological sites associated with raised fields, which indicate a high consumption of cultivated plants. Grinding stones (metates and manos) are present in many sites. They probably were used to prepare maize. Graters made on rough granite slabs also are found, that could have been used for cassava processing. Ceramic griddles are very common and could have served to cook maize and manioc. Results are still too preliminary to be fully conclusive and more phytoliths need to be studied to learn which plants were predominant in raised fields. Such research, conducted by José Iriarte, is currently underway as part of the present project.

\section{Raised-Field Agriculturalists}

The first raised fields were made in Suriname by the Barrancoid builders of the Buckleburg mounds in $350 \mathrm{AD}$, and probably also in western Guyana [25]. However, most of the earthworks are associated with Arauquinoid sites in Guyana, Suriname, and French Guiana [37]. Along the Guianas coast, Arauquinoid culture spread from the middle Orinoco to the coast of the Guianas [38]. The first Arauquinoid raised fields were made from $650 \mathrm{AD}$, but they became common and spread almost everywhere along the coast up to Cayenne Island between 1000 and 1450 AD. Arauquinoid groups belong to a cultural continuum settled between Cayenne Island and Berbice River in eastern Guyana. This represents a territory of approximately $600 \mathrm{~km}$ in length where the raised field technique was intensively used for almost a thousand years prior to the European conquest. Evidence exists for the emergence of a chiefdom on the Guianas coast in this period. The chiefdom is the prehistoric equivalent of a polity having centralized authority in this region. Such a polity could have been directly involved in the creation of landscape diversity seen today [39]. 
A special find that was made in the swamp near Prins Bernhard Polder, west of the raised fields areas in west Suriname, can be associated with raised fields and to Arauquinoid people. It is a shovel of hardwood (apparently green ebony, Bignonaceae, Tabebuia serratifolia), $72 \mathrm{~cm}$ long, with a flattened, curved end and a broken cylindrical handle (Figure 15). This tool, probably used to make or to maintain earthworks, yielded a Late Arauquinoid dating of 1240-1280 AD [40]. In 1745, Father Gumilla met Otomac Indians who built raised fields with wooden shovels in the Venezuelan Llanos. Similar shovels still exist in some Indian groups such as Ashluslay in Paraguay. In Africa, the Floup from Senegal use a similar wooden shovel, the kayendo, to cut quadrangular blocks in the clay [41]. The block is extracted by pressure of the kayendo against the thigh (Figure 15). Archaeological excavations have shown that the Hertenrits mound was built by the piling up of rectangular blocks, probably made with the same type of wooden shovel.

Figure 15. (a) Arauquinoid wooden shovel found near Prins Bernhard Polder (photo and drawing Rostain). (b) Kayendo from Senegal used to build raised fields by Floup group (photos Montoroi).
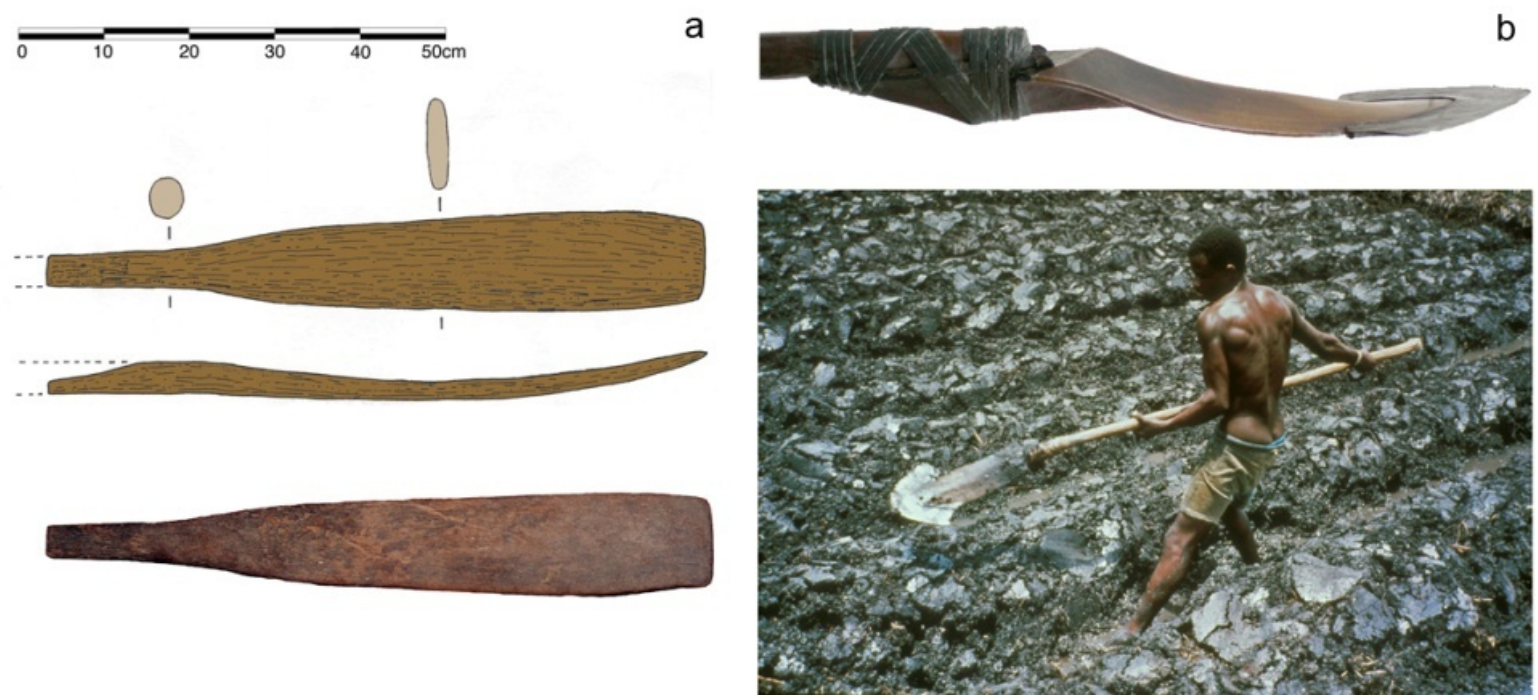

When the European conquest began, most of the raised fields were abandoned in the Guianas and Venezuela. However, some historical sources record Indian agriculture on raised fields in the seasonally flooded savannas of South America, and even in the Caribbean. For example, when the Spanish arrived at Hispaniola in the sixteenth century, the northern plains and the flooded valleys of the center of the island were intensively cultivated with drained fields [42]. In 1536, Juan de Castellanos saw camellones (ridged fields) and calzadas (causeways) in the Venezuelan Llanos, and in 1647 Fray Jacinto de Carjaval mentioned earthworks [43]. In the eighteenth century, Juan Gumilla [35] met Otomac Indians who cultivated on raised fields in the várzea at the confluence of the Orinoco and Apure rivers.

There is almost no mention of Indian raised-field agriculture in the archives of the Guianas. In the seventeenth century, the Palikur of the northern Amapá still numbered 1,200 and disposed less than $150 \mathrm{~km}^{2}$ of dry highland for shifting cultivation. This surface was too small to provide enough food for the group so they made large raised fields in the swamps that they cultivated for several years. Their 
needs fell with population decline, and the size of the raised fields correspondingly reduced to small rounded fields of $80 \mathrm{~cm}$ diameter and 30-40 cm high and rectangular ridged fields of $200 \times 50 \mathrm{~cm}$, surrounded by a ditch for drainage. They cultivated primarily bitter manioc and secondarily the indigenous South American yam (Dioscorea trifida). This technique was abandoned at the end of the nineteenth century [44]. During the eighteenth century, one author noted the use of small mounds to cultivate manioc in the savannas [45]. Otherwise, there are no references to Indian raised-field agriculture in the Guianas during colonial times, which suggests that this technique was very rare or even completely neglected after the European conquest.

\section{Pre-Columbian Demography}

The population in Amazonia has been estimated in the most accurate studies to have been between five and nine million people in 1492 [46,47]. Two centuries later, more than $80 \%$ had disappeared and only 153,000 Indians were still living in the region by 1730 . If the terra firme probably was never densely inhabited, large communities occupied other areas like the várzea on the Amazon and the Orinoco rivers, Andean foothills and Guianas coast.

Through the world, it is striking that raised-field agriculture always corresponds to relatively large populations, raised-field cropping yielding up to $600 \%$ more than flatland cultivation [31). Arauquinoid communities densely populated the coast from around 1000 AD. From looking at the population density in other cultivated tropical lowlands, calculating the surface of raised-field complexes, and estimating their productivity, population density could have been 50 to 100 persons per $\mathrm{km}^{2}$ [20]. This density is very different from classic estimations for Amazonia of one to three inhabitants per $\mathrm{km}^{2}$ [48). However, such numbers are not surprising. In the lower San Jorge River in Colombia, a population of 2,400 people has been estimated in a 1,440 hectare sample area of raised fields with 400 habitation platforms, [12]. More precisely, on the basis of surface area of residential platforms, a population density of 160 persons per $\mathrm{km}^{2}$ is estimated between 200 and $900 \mathrm{AD}$. Some other parts of Amazonia were also densely populated during prehistory. Marajoara communities could have reached 5 to $10 \mathrm{hab} . / \mathrm{km}^{2}$ on Marajó Island [49]. There are estimations of $15 \mathrm{hab} . / \mathrm{km}^{2}$ along the Amazon River [46] and between 6 and $12.5 \mathrm{hab} . / \mathrm{km}^{2}$ in the Upper Xingu [50].

Ethnohistorical and archaeological data from various countries in South America show that flooded savannas or swamps were generally cultivated under demographic pressure, when slash-and-burn agriculture on higher ground became insufficient. Construction, maintenance, and cultivation of raised fields require well-organized and communal work parties. Because the management of hydrological works needs precise planning, it is probable that specialized groups under the leadership of a central authority conducted such labor. It is difficult to evaluate the demography of the raised fields builders, because fields may have been used for longer or shorter periods of time. However, the extension and the number of raised fields suggest population growth on the coast. People who lived in the villages on the sandy ridges did the work necessary to build raised fields and causeways. Long-term sedentarism was possible thanks to a rich coastal biotope and to a permanent agricultural production system. 


\section{Conclusion}

Coastal Guianas are an interesting example of close interaction between humans and the environment in the tropical lowlands of South America. Before the human earth-modifications, coastal savannas were flat and homogeneous. By building raised-fields and canals, pre-Columbian Indians introduced heterogeneity in the landscape, still visible today. Thousands of small mounds, covered by a great diversity of gramineous vegetation, emerge in these large distances uniformly colonized by sedges (Cyperaceae). In fact, the top of the raised fields is covered by secondary vegetation, while primary vegetation, mostly grass, dominates the savanna matrix. By the introduction of an artificial diversity, ancient human action had durably changed the functioning and the ecology of the savannas. Moreover, stereoscopic interpretation of aerial photographs shows an increase of the forest on the periphery of the savannas during the last 40 years. It is reasonable to suggest that pre-Columbian Indians did extend the savanna surface with their earthworks, with the forest gaining ground again after the abandonment of raised-field complexes. During colonial times, human occupation and action were minor in the coastal savannas, so no important remains of this period can be observed on the modern landscape. Conversely, significant landscape transformations and diversity made during pre-Columbian times have changed forever the aspect of these coastal savannas.

Ancient raised fields are known in various countries of South America: the Llanos de Mojos in Bolivia, Lake Titicaca Basin in Bolivia and Peru, Lerma in north Argentina, on the Chile coast, at the mouth of the Guayas River in Ecuador, in the Andean valleys of northern Ecuador, in the La Tolita territory between Ecuador and Colombia, in the savannas of highland Bogotá and along the San Jorge River on the Caribbean coast of Colombia, in the Llanos of Apure in Venezuela, along the eastern coast of Guyana, on the western and eastern coast of Suriname, and on the western French Guiana coast. Most of these earthworks are dated in the first millennium AD, but some of them were made as early as 1000 BC. They were used at least up to European times and probably abandoned because of climatic change and demographic decline.

It is obvious that pre-Columbian Indians intensively transformed coastal savannas of the Guianas (Figure 16). In the flooded savannas, raised fields seem to be the best agricultural answer to population rise because this technique permits intensive land use. Population density could reach 50 to 100 persons per $\mathrm{km}^{2}$ in areas with raised fields. I believe that from $650 \mathrm{AD}$, the intensification of agriculture using the raised-field technique progressively resulted in population growth, social complexity, intersocietal interaction, crafts specialization and long-distance trade; factors which together resulted in the emergence of chiefdoms along the coast of the Guianas. 
Figure 16. Reconstitution of the pre-Columbian landscape near Kourou.

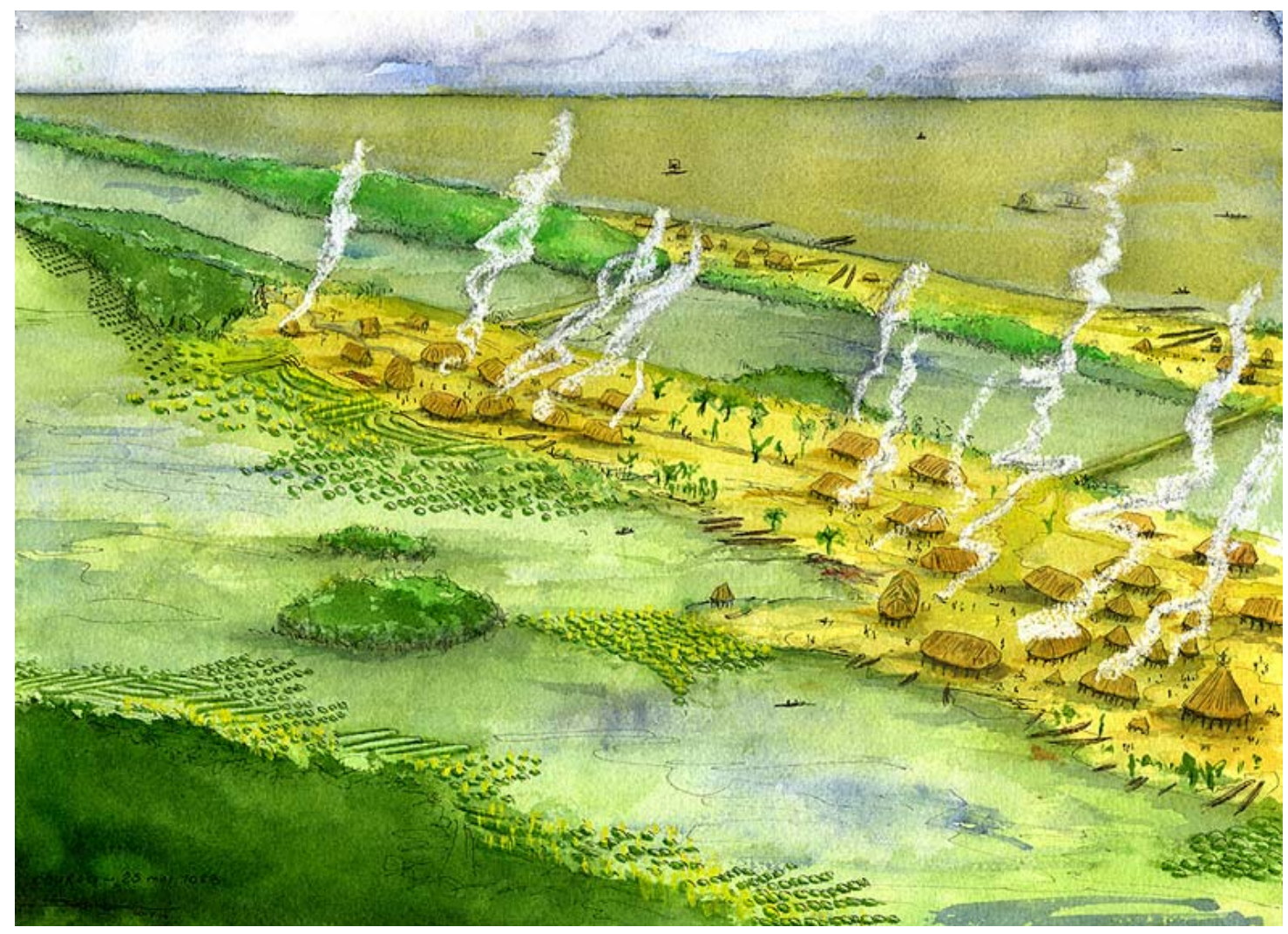

\section{Acknowledgments}

Manuel Arroyo-Kalin (University of Durham, England) provided useful comments on the manuscript.

\section{References}

1. Lescallier, D. Tableau de Cayenne ou de la Gü̈ane Française; Tilliard \& Fils libraires: Paris, France, 1799.

2. Denevan, W.M. Cultivated Landscapes of Native Amazonia and the Andes; Oxford University Press: New York, NY, USA, 2001.

3. Balée, W.; Erickson, C.L. Time and Complexity in Historical Ecology; Columbia University Press: New York, NY, USA, 2006.

4. Rostain, S. Les Champs Surélevés Amérindiens de la Guyane. Coll La Nature et l'Homme, ORSTOM, Cayenne, French Guiana, 1991.

5. Geijskes, D.C. Arowaks in the prehistory of Surinam. In Proceedings of the 1st International Congress for the Study of the Pre-Columbian Cultures of the Lesser Antilles, Fort-de-France, Martinique, France, 1964; pp. 57-70.

6. Boomert, A. Pre-Columbian raised fields in coastal Surinam. In Proceedings of the 6th International Congress for the Study of the Pre-Columbian Cultures of the Lesser Antilles, Gainesville, FL, USA, 1976; pp. 134-144. 
7. Lézy, E. La Guyane, un territoire de légende en marge de toutes les cartes. In Cahiers de l'Amérique Latine, Special "La Guyane, une île en Amazonie”, 43, Paris, France, 2004; pp. 39-66.

8. Richard-Hansen, C.; Le Guen, R. Guyane ou le voyage écologique. Éditions Roger Le Guen: Garies: Northern Cape, South Africa, 2002.

9. Denevan, W.M. The aboriginal cultural geography of the Llanos de Mojos of Bolivia, IberoAmerica 48; University of California Press: Berkeley/Los Angeles, CA, USA, 1966.

10. Erickson, C.L. Amazonia: the historical ecology of a domesticated landscape. In Handbook of South American Archaeology; Silverman, H., Isbell, W.H., Eds.; Springer/Kluwer/Plenum, New York, NY, USA, 2008; pp. 157-184.

11. Prümers, H. Hügel umgeben von "schönen Monstern": Ausgrabungen in der Loma Mendoza (Bolivien). In Expeditionen in Vergessene Welten. 25 Jahre archäologische Forschungen in Amerika, Afrika und Asien (AVA-Forschungen, Bd. 10), Aachen, Germany, 2004; pp. 47-78.

12. Plazas, C.; de Saenz, A.M. Falcheti Poblamiento y adecuación hidráulica en el bajo Río San Jorge, Costa Atlantica, Colombia. In Pre-Hispanic Agricultural Fields in the Andean Region, BAR International Series 859; Archaeopress: Oxford, UK, 1987; pp. 483-503.

13. Zucchi, A. Recent evidence for Pre-Columbian water management systems in the Western Llanos of Venezuela. In Prehistoric Intensive Agriculture in the Tropics; Farrington, I., Ed.; BAR International Series 232; Archaeopress: Oxford, UK, 1985; pp. 167-180.

14. Spencer, C.S.; Redmond, E.M.; Rinaldi, M. Drained fields at La Tigra, Venezuelan Llanos: a regional perspective. Lat. Am. Antiq. 1994, 5, 95-110.

15. Dillehay, T.D.; Pino Quivira, M.; Bonzani, R.; Silva, C.; Wallner, J.; Le Quesne, C. Cultivated wetlands and emerging complexity in south-central Chile and long distance effects of climate change. Antiquity 2007, 81, 949-960.

16. Denevan, W.M.; Mathewson K. Preliminary result of the Samborondón raised-field project, Guayas Basin, Ecuador. BAR International Series 189; Archaeopress: Oxford, UK, 1983; pp. 167-181.

17. Boada Rivas, A.M. Patrones de asentamiento regional y sistemas de agricultura intensiva en Cota y Suba, Sabana de Bogotá (Colombia), Fundación de Investigaciones Arqueológicas Nacionales, Banco de la República: Bogotá, Columbia, 2006.

18. Mothes, P. Actividad volcánica y pueblos precolombinos en el Ecuador; ediciones Abya-Yala: Quito, Ecuador, 1998.

19. Erickson, C.L. The lake titicaca basin. A precolumbian built landscape. In Imperfect Balance: Landscape Transformations in the Precolumbian Americas; Lentz, D.L., Ed.; Columbia University: Columbia, NY, USA, 2000; pp. 311-356.

20. Rostain, S. Agricultural Earthworks on the French Guiana Coast. In Handbook of South American Archaeology; Silverman, H., Isbell, W., Eds.; Springer/Kluwer/Plenum: New York, NY, USA, 2008; pp. 217-234.

21. Boomert, A. Hertenrits: an Arauquinoid Complex in North West Suriname. J. Walter Roth. Mus. 1980, 3, 68-104.

22. Plew, M.G. The Archaeology of Guyana. BAR International Series 1400; Archaeopress: Oxford, UK, 2005. 
23. Cornette, A. Quelques données sur l'occupation amérindienne dans la région basse Mana, bas Maroni, d'après les sources ethno-archéologiques. In Equinoxe 24, CEGER: Cayenne, French Guiana, 1987; pp. 70-99.

24. Boomert, A. Pre-Columbian raised fields in Coastal Surinam. In Proceedings of the 6th International Congress for the Study of the Pre-Columbian Cultures of the Lesser Antilles, Gainesville, FL, USA, 1976; pp. 134-144.

25. Versteeg, A.H. Barrancoid and Arauquinoid mound builders in coastal Suriname. In Handbook of South American Archaeology; Silverman, H., Isbell, W.H., Eds.; Springer/Kluwer/Plenum, New York, NY, USA, 2008; pp. 303-318.

26. Werkhoven, M.C.M.; Versteeg, A.H. The Vegetation of Four Mounds in the Coastal Plain of Suriname. Mededelingen Surinaams Museum 1980, 32, 8-37.

27. Balée, W. The culture of Amazonian forests. In Resource Management in Amazonia. Indigenous and Folk Strategies; Posey, D.A., Balée, W., Eds.; The New York Botanical Garden: Bronx, NY, USA, 1989; pp. 1-21.

28. Redmond, E.M.; Spencer, C.S. Archaeological Survey in the High Llanos and Andean Piedmont of Barinas, Venezuela. In Anthropological Papers of the American Museum of Natural History, No. 86; American Museum of Natural History: New York, NY, USA, 2007.

29. The National Planning Office of Suriname \& Regional Development and Physical Planning Department, Suriname Planatlas, Washington, DC, USA, 1988.

30. Rostain, S. La mise en culture des marécages littoraux de Guyane à la période précolombienne récente. In Milieux, sociétés et archéologues; Marliac, Ed.; éditions ORSTOM/Khartala: Paris, France, 1995; pp. 119-160.

31. Denevan, W.N.; Turner, B.L., II Forms, Functions and Associations of Raised Fields in the Old World Tropics. J. Trop. Geogr. 1974, 39, 24-33.

32. Darch, J.P. Drained Field Agriculture in Central and South America. BAR International Serie 189; Archaeopress: Oxford, UK, 1983.

33. Denevan, W.M.; Mathewson, K.; Knapp, G. Pre-Hispanic Agricultural Fields in the Andean Region. BAR International Serie 359; Archaeopress: Oxford, UK, 1987.

34. Roosevelt, A.C. Parmana. Prehistoric Maize and Manioc Subsistence along the Amazon and Orinoco. Academic Press: New York, NY, USA, 1980.

35. Gumilla, J. El Orinoco Ilustrado y Defendido. Biblioteca de la Academia Nacional de la Historia: Caracas, Venezuela, 1963.

36. Rostain, S. Préhistoire de l'Amazonie française. BAR Paris Monograph (in press); Archaeopress: Oxford, UK.

37. Rostain, S. L'occupation Amérindienne Ancienne du Littoral de Guyane. TDM 129. ORSTOM editions: Paris, France, 1994.

38. Rostain, S.; Versteeg, A.H. The Arauquinoid Tradition in the Guianas. In Late Ceramic Societies in the Eastern Caribbean; Delpuech, Hofman, Eds.; BAR 1273. Paris Monographs in American Archaeology; Archaeopress: Oxford, UK, 2004; pp. 233-250.

39. Rostain S. Cacicazgos guyanenses: mito o realidad? Proceedings of the $1^{\text {ero }}$ Encontro Internacional de Arqueologia Amazônica; MPEG: Belém, Brazil, 2008. 
40. Versteeg, A.H. Suriname voor Columbus/Suriname before Columbus; Libri Musei Surinamensis 1, Stichting Surinaams Museum: Paramaribo, Suriname, 2003.

41. Rostain, S. Le littoral des Guyanes, héritage de l'agriculture précolombienne. In Études rurales, Varia 181; éditions de l'EHESS, Paris, Frances, 2008; pp. 9-38.

42. Dreyfus, S. Notes sur la chefferie Taino d'Aiti: capacités productrices, ressources alimentaires, pouvoirs dans une société précolombienne de forêt tropicale. Journal de la Société des Américanistes LXIV 1981, 229-248.

43. Zucchi, A.; Denevan, W.M. Campos Elevados e Historia Cultural Prehispánica en los Llanos Occidentales de Venezuela; Universidad Católica Andres Bello/Instituto de Investigaciones Históricas: Caracas, Venezuela, 1979.

44. Grenand, P. Agriculture sur brûlis et changements culturels: le cas des Indiens Wayãpi et Palikur de Guyane. Journal d'Agriculture Traditionnelle et de Botanique Appliquée 1981, XXVIII, 23-31.

45. Barrère, P. Nouvelle relation de la France Equinoxiale. Piget-Damonneville, Durand, Paris, 1743.

46. Denevan, W.M. Native american populations in 1492: recent research and a revisited hemisperic estimate. In The Native Population of the Americas in 1492; Denevan, W.M., Ed.; University of Wisconsin Press: Madison, WI, USA, 1992, xvii-xxxviii.

47. Woods, W.I.; Denevan, W.M.; Rebellato, L. Population estimates for anthropogenically enriched soils (amazonian dark earths). In Living on the Land: The Complex Relationship Between Population and Agriculture in the Americas; Wingard, J., Hayes, S.E., Eds.; University of Colorado Press: Boulder, CO, USA, 2010 (In press).

48. Meggers, B.J. Suposiciones de grandes y densas poblaciones prehistóricas en la Amazonía, evaluadas a partir de las evidencias arqueológicas, etnográficas y ecológicas. In Amazonía peruana, Centro Amazónica de Antropología y Aplicación Práctica, Lima, Peru, 2008; pp. 21-56.

49. Roosevelt, A.C. Moundbuilders of the Amazon: Geophysical Archaeology on Marajó Island, Brazil; Academic Press: New York, NY, USA, 1991.

50. Heckenberger, M.J.; Kuikuro, A.; Kuikuro, U.T.; Russell, J.C.; Schmidt, M.; Fausto, C.; Franchetto, B. Amazonia 1492: Pristine forest or cultural parkland? Science, 2003, 301, 1710-1714.

(C) 2010 by the author; licensee Molecular Diversity Preservation International, Basel, Switzerland. This article is an open-access article distributed under the terms and conditions of the Creative Commons Attribution license (http://creativecommons.org/licenses/by/3.0/). 